\title{
Neuroleptic malignant syndrome in clinical practices
}

\author{
Snežana M. Bugarinović́ ${ }^{1}$ Snežana S. Đorđević ${ }^{1}$, Olivera R. Savić ${ }^{1}$, \\ Tijana M. Mirjanić ${ }^{1}$
}

${ }^{1}$ Special Hospital for Psychiatric Diseases “Kovin”, Kovin, Serbia

\section{SUMMARY}

Topic: Neuroleptic Malignant Syndrome is a rare but specific lethal reaction to neuroleptics / antipsychotics.It occurs in $0.02 \%$ to $3.3 \%$ of patients in the treatment applying conventional neuroleptic drugs. Neuroleptic malignant syndrome is associated with highly potent antipsychotic drugs. However, it can occur more frequently in patients treated with atypical antipsychotics such as clozapine.

Topic position in medical public: Neuroleptic malignant syndrome is critical medical condition, potentially threatening complication associated with side effects of neuroleptic drugs. High levels of creatine kinase (CK) and leukocytosis are associated with neuroleptic malignant syndrome.

Future action: Neuroleptic malignant syndrome as a psychiatric entity requires permanent research, early diagnosis, adequate therapy, exchange of clinical experiences, and what's of particular importance, rational antipsychotic administration.

Keywords: antipsychotics, increased serum creatine kinase (CK),clinical signs

\section{TOPIC}

Neuroleptic Malignant Syndrome (NMS) is a rare but specific lethal reaction to neuroleptics / antipsychotics. Neuroleptic malignant syndrome related to the treatment of antipsychotic haloperidol was first described in 1960 by the Delay and associates [1]. Although estimates incidence of neuroleptic malignant syndrome used to be even $3 \%$ of patients treated with antipsychotics, more recent data suggests incidence of $0.01 \%-0.02 \%$ [2]. It is most often associated with typical highly potent antipsychotic drugs (e.g. haloperidol, fluphenazine) [3]. However, every class of antipsychotics implied, including low potent (e.g. chlorpro- mazine), newer atypical antipsychotics (e.g. clozapine, risperidone, olanzapine) and antiemetic medicines (e.g. metoclopramide, promethazine). Neuroleptic malignant syndrome is characterized by fever, muscle rigidity, altered mental status, autonomic dysfunction and increased creatine kinase [4 - 5].

\section{TOPIC POSITION IN MEDICAL PUBLIC}

\section{Pathophysiology}

Although the precise pathophysiological mechanisms related to neuroleptic malignant syndrome have not been proven, the blockade of dopamine due to antipsychotics, plays a ma- 
jor role as a trigger for this condition [6]. Several arguments support this assumption:

- withdrawal of dopaminergic drugs participating in neuroleptic malignant syndrome;

- all drugs associated with malignant neuroleptic syndrome caused by dopamine receptor blockade;

- seems that the risk of neuroleptic malignant syndrome correlates with affinity of drugs for binding to dopamine receptors;

- dopaminergic drugs are used to treat neuroleptic malignant syndrome, and it is noticed that patients with lesions of the central dopamine pathways develop syndromes sharing many clinical characteristics with neuroleptic malignant syndrome.

The central role of dopaminergic hypofunction is further supported by observation that the concentration of dopamine metabolites and homovanillic acid in cerebrospinal fluid is low in patients with acute neuroleptic malignant syndrome [7]. Polymorphisms in the dopamine 2 receptor gene in patients who have recovered from neuroleptic malignant syndrome have been researched in several preliminary studies, although the results are not consistent [8]. However, the direct effect on peripheral skeletal muscles may have an additional role. Based on autonomic dysfunction observed in the last two decades related to the neuroleptic malignant syndrome and on observed increased values of catecholamine in many cases, it was pointed out that symphatoadrenal dysfunction has a role in contributing to neuroleptic malignant syndrome. Whatever mechanism causes neuroleptic malignant syndrome, pathophysiology of neuroleptic malignant syndrome is probably complicated and includes dysregulation cascade of multiple neurochemical and neuroendocrine system that culminate on the closing stage of hypermetabolic syndrome [9].

\section{Pathogenesis}

Neuroleptic malignant syndrome may occur as a result of changes in pre-/or posthypnotic dopaminergic signals. There are two mechanisms:

1. Reduced DA signals as a result of the sudden withdrawal of dopaminergic drugs.

2. Initiating the agents which block DA signals [9].

There is great probability that neuroleptic malignant syndrome shall occur after starting treatment with antipsychotics or after increasing doses of the drug. Initiating neuroleptic malignant syndrome symptom may occur after a few hours, but on average, begins from 4 to 14 days after starting treatment.

Four characteristics that define neuroleptic malignant syndrome are as follows:

1. Motor symptoms

2. Altered mental status

3. Hyperthermia

4. Autonomic instability.

\section{Motor symptoms}

Due to inclusion of the basal ganglia, the primary motor characteristic is rigidity or socalled 'lead bar'. Other motor irregularities include akinesia/bradykinesia, dystonia, inability to speak, chorea, dysarthria and tremor [10].

\section{Altered mental status}

Alternations in mental status ranging from confusion, delirium and stupor to coma are very common at neuroleptic malignant syndrome [11].

\section{Hyperthermia}

Fever higher than $38^{\circ} \mathrm{C}$ often occurs, and sometimes exceeds $41^{\circ} \mathrm{C}$ [12].

\section{Autonomic instability}

Autonomic dysfunction is manifested by respiratory irregularities, cardiac arrhythmia, variable blood pressure, incontinence and diaphoresis [13].

\section{Diagnosis}

Despite the available criteria, it is usually hard to distinguish neuroleptic malignant syndrome from frequent extrapyramidal undesired effects and other disorders occurring in similar symptoms; Criteria for researching DSM IV TR require presence of strong muscular rigidity and increased fever after the imminent application of antipsychotics. All three main criteria (fever, rigidity, increased serum creatine kinase), or two main and four secondary criteria (tachycardia, variable blood pressure, altered state of consciousness, diaphoresis, leukocytosis) indicate great probability of neuroleptic malignant syndrome if corroboratedclinically [14]. Laboratory tests include:

- Increased serum creatine kinase (CK);

- Other laboratory irregularities [3].

Increased serum creatine kinase: In neuroleptic malignant syndrome, CK is usually higher than $1.000 \mathrm{IU} / \mathrm{L}$ and may reach 100.000 
IU/L. Increased CK value shows rhabdomyolysis as secondary in respect of muscular rigidity. It seems that the level of increased CK is in direct correlation with seriousness of the disease and higher value in accordance with prognosis [2 3]. The second most consistent finding is leukocytosiswith white blood cell count of 10.000 to 40 . 000. Laboratory value of leukocytes can be shifted to left. Lactate dehydrogenase (LDH), alkaline phosphatase, and liver transaminase are frequently leniently increased. Irregularities of electrolytes in terms of hypocalcemia, hypo- or hypernatremia, hyperkalemia and metabolic acidosis are often noticed. Myoglobinuric acute renal failure may be the result of rhabdomyolysis. Low concentration value of iron in serum (mid value $5.71 \mu \mathrm{mol} / \mathrm{L}$ ) is often found in neuroleptic malignant syndrome and it is sensitive but not specific marker for neuroleptic malignant syndrome in acute patients.

Serious cases of neuroleptic malignant syndrome may be followed by stupor and coma. In these circumstances, lumbar puncture CSF may be implied to evaluate alternative cause and determine whether there is a threatening cerebral edema due to metabolic disorders.

Differential diagnosis of neuroleptic malignant syndrome divide into two categories:

1. Conditions associated with neuroleptic malignant syndrome

2. Conditions unrelated to neuroleptic malignant syndrome

Conditions associated with neuroleptic malignant syndrome are as following:

- Serotonin syndrome

- Malignant hyperthermia

- Malignant catatonia

- Acute lethal catatonia

- Central cholinergic syndrome

- Metabolic encephalopathy/ encephalitis

Conditions unrelated to neuroleptic malignant syndrome:

- infection of the central nervous system (meningitis / encephalitis)

- Heat stroke

- Delirium tremens

- Parkinsonism

- Acute porphyria

- Septic shock

- Tetanus

- Strychnine intoxication

- Pheochromocytoma

\section{FURTHER ACTION}

\section{Treatment}

Neuroleptic malignant syndrome is critical case and may lead to death if not treated. The first step includes immediate recognition of neuroleptic malignant syndrome, immediate termination of antipsychotic drugs and exclusion of other medical conditions. Supportive medical care, specific pharmacotherapy and electroconvulsive therapy are useful in the overall treatment.

\section{Supportive medical care}

Neuroleptic malignant syndrome requires aggressive therapy. However, supportive care forneuroleptic malignant syndrome is absolutely vital. Complications are common, severe and even fatal.

- dehydration

Complications include:

- imbalance of electrolytes

- acute renal failure with rhabdomyolysis

- cardiac arrhythmia including the cardiac ar-

rest

- myocardial infarct

- cardiomyopathy

- respiratory arrest due to rigidity of chest cavity wall, aspiration pneumonia, pulmonary embolism

- deep vein thrombosis

- thrombocytopenia

- disseminated intravascular coagulation

- attacks due to hyperthermia and metabolic disorders

- hepatic hemorrhage arrest

- septicemia

Intensive monitoring and supportive treatment require admission to the intensive care unit. The following supportive treatment should be provided:

- canceling antipsychotic drug administration or precipitating medicine

- maintaining cardiorespiratory stability. However, mechanic ventilation and antiarrhythmicdrugs may be required.

- maintaining euvolemic state using intravenous fluids. Unplanned loss of fluids due to fever and diaphoresis should be also considered.

- decreasing temperature by chilling and using antipyretics.

-decreasing blood pressure, if it is significantly increased 


\section{Pharmacotherapy}

Conventional substances are dantrolene, bromocriptine and amantadine. It seems that clinical preferences determine the use of bromocriptine and/or dantrolene.In patients with strong muscle rigidity, rhabdomyolysis and extreme hypothermia, applying intravenous dantrolene may have advantage, with or without administering bromocriptine. Treatment is continued for at least 10 days. Early termination of treatment can precipitate the recurrence of neuroleptic malignant syndrome. Treatment with depot antipsychotics should be continued 2 to 3 weeks after clinical recovery.

\section{CONCLUSION}

NMS as psychiatric and biochemical entity requires:

- permanent research including genetic research

- early diagnosis

- adequate therapy

- interchanging clinical experiences

- and, most importantly, rational antipsychotic administration.

\section{REFERENCES}

1. Delay J, Pichot P, Lemperiere T, et al. A nonphenothiazine and nonreserpine major neuroleptic, haloperidol, in the treatment of psychoses. Ann Med Psychol (Paris). 1960; 118(1):145-52.

2. Stubner S, Rustenbeck E, Grohmann R, Wagner $G$, Engel R, Neundorfer G, Moller HJ, Hippius H, Ruther $E$ : Severe and uncommon involuntary movement disorders due to psychotropic drugs. Pharmacopsychiatry 2004; 37(suppl 1):S54-S64

3. Chandran GJ, Mikler JR, Keegan DL. Neuroleptic malignant syndrome: care report and discussion. CMAJ. 2003; 169(5):439-42.

4. Kogoj A, Velikonja I. Olanzapine induced neuroleptic malignant syndrome-a case review. Hum Psychopharmacol. 2003; 18(4):301-9.

5. Strawn JR, Keck PE, Caroff SN. Neuroleptic malignant syndrome. Am J Psychiatry. 2007; 164(6):870876.

6. Mann SC, Caroff SN, Fricchione G, Campbell EC: Central dopamine hypoactivity and the pathogenesis of the neuroleptic malignant syndrome. Psychiatr Ann 2000; 30:363-374

7. Nisijima K, Ishiguro T: Cerebrospinal fluid levels of monoamine metabolites and gamma-aminobutyric acid in neuroleptic malignant syndrome. J Psychiatr Res 1995; 27:233-244
8. Caroff SN: Neuroleptic malignant syndrome, in Neuroleptic Malignant Syndrome and Related Conditions, 2nd ed. Edited by Mann SC, Caroff SN, Keck PE Jr, Lazarus A. Washington, DC, American Psychiatric Publishing, 2003, pp 1-44

9. Gurrera RJ: Sympathoadrenal hyperactivity and the etiology of neuroleptic malignant syndrome. Am J Psychiatry 1999; 156: 169-180

10. Levenson JL. Neuroleptic malignant syndrome. Am J Psychiatry. 1985; 142(10):1137-45.

11. Koch M, Chandragiri S, Rizvi S, et al. Catatonic signs in neuroleptic malignant syndrome. Compr. Psychiatry. 2000; 41(1):73-5.

12. Caroff SN, Mann SC. Neuroleptic malignant syndrome. Med Clin North Am. 1993; 77(1):185-202.

13. Rosebush P, Stewart T. A prospective analysis of 24 episodes of neuroleptic malignant syndrome. Am J Psychiatry. 1989; 146(6):717-25.

14. American Psychiatric Association: Diagnostic and Statistical Manual of Mental Disorders, 4th ed. Washington, DC, American Psychiatric Association, 1994. 


\section{Maligni neuroleptički sindrom u kliničkoj praksi}

Snežana M. Bugarinović ${ }^{1}$, Snežana S. Đorđević ${ }^{1}$, Olivera R. Savić ${ }^{1}$, Tijana M. Mirjanić ${ }^{1}$

${ }^{1}$ Specijalna bolnica za psihijatrijske bolesti „Kovin”, Kovin, Srbija

\section{KRATAK SADRŽAJ}

Tema: Maligni neuroleptički sindrom je retka, ali po život opasna osobena reakcija na neuroleptike/ antipsihotike. Javlja se kod 0,02\% do 3,3\% pacijenata koji u terapiji koriste konvencionalne neuroleptičke lekove. Maligni neuroleptički sindrom povezuje se sa visokopotentnim antipsihotičkim lekovima. Međutim, može da se javi i kod bolesnika lečenim atipičnim antipsihoticima, češće kod primene klozapina.

Pozicioniranost teme u medicinskoj javnosti: Maligni neuroleptički sindrom je hitno stanje u medicini, komplikacija potencijalno opasna po život povezana sa neželjenim dejstvom neuroleptičkih lekova. Visok nivo kreatin kinaze (CK) i leukocitoza povezani su sa maignim neuroleptičkim sindromom.

Buduće aktivnosti: Maligni neuroleptički sindrom kao psihijatrijski entitet zahteva permanentna istraživanja, ranu dijagnozu, adekvatnu terapiju, razmenu kliničkih iskustava, i što je od posebnog značaja, racionalnu upotrebu antipsihotika.

Ključne reči: antipsihotici, povišena vrednost serumske kreatin kinaze (CK), klinički znaci 